\title{
On the Threshold Knowledge, Hybridity, and Gender in August Strindberg's I havsbandet
}

\author{
Irina Hron-Öberg \\ Stockholm University
}

Finns det nu något system i denna galenskap? -Strindberg, "Blomstrens Hemligheter"

\begin{abstract}
Trindberg's novel I havsbandet, published in I890, introS duces the isolated world of the Swedish archipelago as a border zone between open sea and land, order and disorder, and law and lawlessness. Along the Swedish coast, the well-defined waterline is broken up into a cluster of scattered islands and thus expanded from a border line into a border area - a setting recurrent in Strindberg's prose. ${ }^{2}$ Accordingly, the eponymous havsband [chain of skerries], reduplicated in the novel's original title, ${ }^{3}$ does not only provide the scenery for the text, but also an aesthetic space in its own right, experimenting with and challenging traditional spatial demarcations ${ }^{4}$ : the skärgård [skerry

I. 2I3 [Is there any system in this madness?]. All translations from Swedish and German, unless otherwise attributed, are my own.

2. Other texts placed in an archipelago setting are, for example, the novel Hemsöborna, the collection Skärkarlsliv, or the short novel Silvertrüsket. As A. Westerståhl Stenport points out, the literary setting in Strindberg's works and his "experimental conception of the spatio-temporal" is highly significant, offering ways to "redefine and rewrite a marginal literary identity at the end of the nineteenth century" (4).

3. As an aside, it is interesting to note that both the English translation of the title, $B y$ the Open Sea, and the German translation, Am offenen Meer, focus on the waterside aspect of the transitional space of the archipelago.

4. According to the article on "Avantgarde" [avant-garde] in the 2000 edition of the German historical dictionary of aesthetics, the figure of boundary-crossing is a core element in the definition of the avant-garde (see Barck 545 et seq.). Referring to Karlheinz Barck's elaboration on the term, my article does not seek to provide a definition of avant-garde, but rather illustrates how Strindberg's text engages notions of radicalism and avant-garde by creating spatial hybridity (bavsband) and linguistic double-movements through gendering and a poetization of scientific language.
\end{abstract}


landscape], as I will argue, is a multiply stratified space composed of several diverse wild elements. Consequently, this "transitional area with a gradual change from a terrestrial to a maritime environment" (Storå $448)$ is a hybrid space that has to be domesticated and systematized in order to become habitable. Against this background, Axel Borg, the protagonist of the text, sets out to tame the wild: the raging sea and the untilled island. Yet, instead of simply assuming the role of the colonizer who appropriates a place for his own use, Borg stages himself as vanguard in the original military meaning of the word avant-garde: he is the "Träger des Fortschritts" (Barck 544) [bearer of progress], a self-appointed pioneer who, in the end, perishes because he utterly fails to establish control over the colonized. Moreover, Strindberg's novel presents, represents, and exemplifies the literary and imaginary aspects of scientific language, redefined as a male and poetic language of power. Through science and scientific naming the technocrat Borg seeks to establish a different and experimental order of things: a new law of how to know and how to name properly. Accuracy and precision down to the last detail are the main qualities of Borg's scientific language, and he presents himself as the perfect Homo sapiens, the "knowing man." The designation Homo sapiens was introduced by Carl Linnaeus, ${ }^{5}$ who was probably the first to place man in a neat system of biological classifications. Accordingly, Linnaeus and his ingenious taxonomies play a crucial role when it comes to questions of classification, nomenclature, and in particular Borg's highly gendered nomenclature.

This article analyzes the relation between science, hybrid space, ${ }^{6}$ and radical (gendered) language by exploring the way in which thresholds are crossed and territories entered, occupied, and named by constituting an order that expels a well-defined group of individuals from science and knowledge. Thus, my analysis explicitly challenges the tendencies in previous Strindberg scholarship to reduce the text to its Nietzscheanism, to hurriedly label Borg's language as scientific, and to play down

5. In the following, I will use the standard English convention of referring to him as Carl Linnaeus instead of Carl von Linné as is common in Sweden.

6 . I use the term "hybrid space" neither in the sense of a simultaneous presence of different spatial logics, nor as a postcolonial term, but rather to describe phenomena composed of two or more diverse elements. The reference to the scientist and taxonomist Gregor Mendel and his work on (plant) hybridization is obvious. 
the archipelago setting as a reference to the author's native landscape. ${ }^{7}$ As I will show, assumptions of this kind not only underestimate the radicalism of Strindberg's language, but also neglect the acute tension created by the hybrid setting of I havsbandet, which brings the novel in line with the highly experimental texts of the twentieth century. Introducing the figure of hybridity, the crossing of thresholds and border zones is one of the central images of the following close reading of I havsbandet. Eventually, my approach explores the similarities and differences of scientific and poetic language as well as male and female language and highlights the literary and poetical strategies Strindberg's text uses in order to create a progressive order of (well-constructed) knowledge. Consequently, I would like to suggest that the Swedish archipelago novel not only precedes contemporary theories of civilization and colonization, but also foreshadows seminal mid-twentieth-century theories of space and radical boundary-crossing.

\section{A Thousand Islands: The Archipelago as Hybrid Space}

I. Evoking the landscape of the Swedish archipelago, the title of Strindberg's novel creates an intriguing imagery of borders and border zones. Not only does it provide the text with an elaborate hybrid space "blandad av land och vatten" (Strindberg, "Skärkarlsliv" 9) [blend of land and water] as described in Strindberg's short story collection Skärkarlsliv, it also represents a highly significant geographical location. The Swedish term havsband refers to the outmost edge of the archipelago where the transition from land to water and the exchange and intermixing of elements takes place. This makes it an exemplary hybrid space. The fact that there is no adequate English translation of the word proves the geographical as well as the linguistic limitations of the term. Referring to Blumenberg and his programmatic study Schiffbruch mit Zuschauer [Shipwreck with Spectator], Michael Makropoulos gives an emphatic and quite symptomatic description of the metaphorical boundary

7. See, for example, Walter Berendsohn's extensive book on Strindberg's archipelago depictions. See also Göran Stockenström's article, in which he focuses on the role of both ancient and modern science in Strindberg's work. 
between sea and land. The coastal line, as he points out, functions as the ontological point of contact between two different elements and marks, in an elementary sense, the naturally given borders of the space in which human endeavor takes place. Whereas land borders draw artificial boundaries between inhabited spaces, the coast-line is a perfectly natural boundary transgressable only by means of technological facilities - that is, navigation and nautical technology. Heading for the outer archipelago, Axel Borg is, as we will see, equipped to the teeth with a set of quite unorthodox nautical and meteorological instruments. He is prepared not only to cross the boundaries between the elements, but also to pit himself against the forces of nature, against chaos and disorder, and eventually against savage language. The open sea, like all open space, has to be controlled; it has to be systematized, and this is Axel Borg's task. Once more referring to Blumenberg, (Borg's) seafaring, seen as a transgression of natural boundaries, turns out to be a vital metaphor for existence ${ }^{8}$ that seeks to go beyond the domain clearly demarcated by nature.

II. In the opening scene of the novel, we encounter the protagonist's crossing of several spatial thresholds presented in the figure of the subjugation of natural forces: nature, symbolized by the raging sea, is seemingly tamed by man: "Snart hade han dock studerat sjöarnes harmonilära ... det var såsom om han improviserat nautiska och meteorologiska instrument av sina känsliga sinnen till vilka ledningarne stodo öppna från hans stora hjärnbatteri” (I2) ["He soon taught himself the harmonics of the waves.... It was as if he were improvising nautical and meteorological instruments from his delicate senses, to which cords passed freely from his large brain-battery" (6)]. At first glance, Axel Borg appears as a rational and pragmatic scientist, a man of outstanding ability who knows exactly how to use physical laws to his own advantage - and against nature. Dressed in "ett par krokodilchagrinkängor" (7) ["a pair of crocodile shagreen boots" (I)] and "laxfärgade glacé-handskar-med-tre-knappar" (7) [“salmon-coloured glacé gloves with three buttons" (I)], he exudes delicacy and refinement, but his behavior reveals the supercharged "brain-battery." Here, as well, the nature/culture difference that constitutes the "biological machine" of Borg's brain-battery creates a hybrid construct built of heterogeneous

8. Here, I am referring to the subtitle of Blumenberg's Schiffbruch mit Zuschaner: Paradigma einer Daseinsmetapher (Shipwreck with Spectator: Paradigm of a Metaphor for Existence). 
natural and man-made components: a mechanical brain. Unsurprisingly, Borg not only considers himself the crowning achievement of the evolutionary order as prominently defined by Lamarck and Darwin; he also stages himself as the perfect Homo sapiens, the "knowing man." Apparently, he has "alla kulturens och vetenskapens hjälpmedel" (56) ["all the resources of knowledge and civilisation" (52)] at his command, and his ostentatiously displayed superiority puts him far ahead of his traveling companions and adversaries. Overriding traditional oppositions of natural/cultural, biological/mechanical, and uncultured/cultivated, the text anticipates poststructuralist and deconstructive theory and its assertion that hierarchical oppositions of Western philosophy are unstable, arbitrary, and easily deconstructed. ${ }^{10}$

Not incidentally the narration opens with a boat: "Bemyndigad av folkförsamling och styrelse" (56) ["authorised by parliament and government" (52)], Borg and two fishermen set out for Österskär, an insignificant island in the middle of the Stockholm archipelago, where Borg is supposed to help a village develop new fishing methods. All of a sudden a storm breaks out, and the townsman Borg, who has never navigated a sailing boat before, insists on taking over the helm. By simply using his quick-witted brain and his acute sensory organs, he manages to dock the boat while the experienced boatsmen are completely paralyzed. Self-confident, the technocrat takes over the navigation of the boat, and the topos of the sea voyage confirms what is happening on the protagonist's level. According to Makropoulos, the oceanic cruise stands for the "selbstmächtige Erweiterung des menschlichen Handlungsbereichs" ("Modernität als Kontingenzkultur" 55) [self-empowered expansion of human authority], and he labels it explicitly as a frivolous and blasphemous undertaking, basically aiming at a fundamental transgression of natural boundaries. ${ }^{11}$ At first, Borg's sea voyage seems to lead "mitt i

9. The Latin term Homo sapiens (knowing man) was introduced by Linnaeus who, in the tenth edition of Systema naturae, defined man as a wise and rational being.

Io. It would go beyond the scope of this article to discuss in detail the many implications of a poststructuralist reading of Strindberg's text. In this article I will take a closer look at selected Foucauldian aspects, but the poststructural question with regard to Strindberg is certainly worth further study.

II. Accordingly, Blumenberg points out "daß hier, an der Grenze vom festen Land zum Meer, zwar nicht der Sündenfall, aber doch der Verfehlungsschritt ins Ungemäße und Maßlose zuerst getan wurde" (II) [that here on the boundary between land and sea, what may not have been the fall but was certainly a misstep into the inappropriate and the inmoderate was first taken]. 
fördärvet" (9) [“into destruction" (3)] and "över det svarta svalget" (9) ["over the black abyss" (3)] and is reminiscent of the crossing of the ancient tabula rasa, the "erased tablet," where all distinctions are wiped out. The sea is only one aspect of the text's hybrid setting; it is only one element of the multiply stratified order of the havsband, though an important one: the sea is a primeval space, representing both the lifethreatening elements with which the protagonist has to struggle and the power of nature that has to be overcome by man, e.g. overcome by the male natural scientist. The image of the sea voyage as part of a technocratic world-view aims to dominate nature and natural laws and introduces a set of implicit and explicit masculine power relations that structure the text from the very first chapter, the very first page.

The sailing vessel ${ }^{12}$ represents a space of its own as well: the only way to cross the open space of the Baltic and reach the closed space of the Östersk $\ddot{a r}$-island is by boat. It is the very same water vehicle that, in the end of the text, will carry Borg out onto the open sea and, presumably, to his death by drowning. The idea of the boat as a self-contained place of its own has been investigated by Michel Foucault in his 1967 essay "Des espaces autres" (Different Spaces). Referring to this highly influential text, I suggest that the first chapter of I havsbandet, i.e. the voyage by boat, contains elements that anticipate Foucault's theory of heterotopia and thus prefigures aspects of critical theory of the midtwentieth century: according to Foucault, the ship is the heterotopia ${ }^{13}$ par excellence, a "lieu sans lieu" (762) ["placeless place" (I85)], and a "morceau flottant d'espace" (762) ["piece of floating space" (I84)]. In order to reach his final destination, the island, Borg is forced to adjourn to a self-enclosed placeless place. Only the placeless technical vehicle makes it possible for him to cross the wild and primeval space of the open sea. Gillian Beer, in her inspiring essay on "Darwin's Islands," has pointed to the function of the ship as an "intensified form of a national floating island, preserving rigorously the forms of the home community" (I34). Consequently, the "placeless place" resembles an island and anticipates the insular space Borg is about to enter. This emphasizes even more the importance of the novel's island setting, which is by no

I2. Skötöka (herring-boat) is actually the very first word of the text.

I3. Foucault defines heterotopia as "lieux qui sont hors de tous les lieux, bien que pourtant ils soient effectivement localisables" ("Des espaces autres" 755) ["places that are outside all places, although they are actually localizable" (178)]. 
means accidental and must therefore not be reduced to a hermeneutic, biographical reference to the author. Both Foucault and Beer highlight the exclusivity of the "boat space" that functions according to its own rules. All the more, it becomes apparent that the command of the floating vehicle in the novel's opening sequence is solely a question of technique and knowledge. Seamanship, the art or science of operating a boat, and the art of warfare are set parallel, and the question of steering and navigation becomes a question of scientific superiority as is the case in the scene between Borg and the two boatsmen. The ship is turned into a weapon in the fight against nature; it becomes an icon of the supremacy of technical knowledge.

Eventually, the wreckage also becomes part of the human seafaring story. Blumenberg argues that it essentially belongs to the narration of self-empowerment since the shipwreck, seen by a survivor, must be considered a "Figur einer philosophischen Ausgangserfahrung" (I5) [figure of an initial philosophical experience]. Borg's sea voyage ends with a shipwreck, and consequently the story of the collision of the untamed nature and man's will to power turns out to be, as we will see, the story of the failed colonizer.

Finally, Borg is thrown upon land, the space that proves to be his "prövostenen eller förargelseklippan" (46-7) [“"touchstone' or 'stumbling-block"' (43)]: the (untilled) island. This island is not only situated in the middle of a border zone; it is itself a multi-layered wild space, inhabited by a handful of wild people speaking a wild language.

III. Islands are by definition hybrid spaces. Turning to the etymology of the term, the Oxford Dictionary of English not only lists denotations like "watery" and "watered", but also the highly suggestive "waterland," even "river-land." Just as the archipelago and the open sea, the island too is a compact originary space. In Fundamenta Botanica, Carl Linnaeus notes: "I begynnelsen fanns endast en liten ö, på vilken allt som Skaparen bestämt för människans bruk återfanns" (22I) [in the beginning there was only a small island where everything the Creator had intended for man's use could be found]. The Linnaean topos of the primordial island, ${ }^{14}$ an exemplary primal scene, is crucial to the following reading. Biblical imagery can be found throughout the text,

I4. For more on the island as imaginary space and primal scene, see Frängsmyr, who focuses on Linnaeus's notion of paradise as an island. 
but the Mosaic Garden of Eden ${ }^{15}$ is certainly one of the most striking examples. The archetypal place from which Adam and Eve were expelled for disobediently eating from the tree of knowledge is a place that requires cultivation and, consequently, the paradisiac image introduces the aspects of domestication, knowledge, and naming. Furthermore, the island setting turns the story of $I$ havsbandet into a (Darwinian) evolutionary story, referring to Darwin's "case of an island" (64). ${ }^{16}$ Once more citing Gillian Beer, the island is a closed domain "in which the process of variation and of natural selection may be observed working in a high degree of undisturbed historical continuity" (I2O). The island with the Darwinian signature turns out to be an isolated space where nature reigns according to its own rules.

The Robinsonade, the universally recognizable cultural narration of the island story, is the third layer. After his arrival on what he deems to be an uncivilized island, Borg immediately sets out to establish basic cultural techniques such as "potatisodling" (55) [potato cultivation] or "salta [fisk] med tångaska" (55) ["salting down fish ... with seaweed ash" (5I)]. However, the insulars do not accept him as the bearer of civilization and categorically refuse his colonizing efforts. The tension between several disparate stories of civilizing efforts - the Robinsonade, the colonization narrative, or Darwin's “insular” theory of the evolution of species by natural selection-is certainly one of the most intriguing and cutting-edge aspects of Strindberg's text. ${ }^{17}$ In this light, the island to be colonized, too, appears as a diverse and multifarious imaginary space.

15. Compare Genesis 2:8-9: "And the LORD God planted a garden in Eden, in the east; and there he put the man whom he had formed. Out of the ground the LORD God made to grow every tree that is pleasant to the sight and good for food, the tree of life also in the midst of the garden, and the tree of the knowledge of good and evil." Biblical citations follow the New Revised Standard Version of the Bible (NRSV).

I6. Compare: "Let it be remembered how powerful the influence of a single introduced tree or mammal has been shown to be. But in the case of an island, or of a country partly surrounded by barriers, into which new and better adapted forms could not freely enter, we should then have places in the economy of nature which would assuredly be better filled up, if some of the original inhabitants were in some manner modified; for, had the area been open to immigration, these same places would have been seized on by intruders" (23). 17. In the interest of brevity it is impossible to discuss in detail the importance of Darwinian terminology as reflected in Strindberg's text. For a more thorough analysis, see my forthcoming publication with Rombach, due to be published in spring 2013 . 
Together, the archipelago landscape, the (open) sea, and the multilayered island create the textual cosmos of a dense hybrid space where spatial borders are crossed and imaginary thresholds transgressed. Against the backdrop of the transitional and rocky landscape of the Swedish archipelago, Borg and his text invent a radical language which turns out to be a border phenomenon as well-oscillating between the borders of science and poetry, male and female.

\section{Close to the Edge: Scientization AND SeXualization of LANGUAge ${ }^{18}$}

During the nineteenth century natural scientists were obsessed with defining, mapping, and categorizing nature and natural phenomena; August Strindberg was one of them. Like many of his contemporaries, he adapted various classification instruments such as registers, encyclopedias, or other elaborate classification systems. Taxonomy is the keyword to understanding the scientific landscape of this era: the French naturalist Jean-Baptiste de Lamarck is considered the first to develop a systematic theory of descent thus preceding Charles Darwin. Gregor Mendel conducted intensive research in the area of genetics, while Dmitri Mendeleev arranged the elements in the periodic table according to their atomic weight. This recalls Axel Borg's numerous attempts to command and to classify the disordered cosmos in and around him.

In light of this, it is worth noting that many traditional interpretations of Strindberg's novel simply affirm the scientific character of both language and imagery used throughout the text. Such an approach does not, however, contribute to a better understanding of the challenging and at times excessively elaborate way in which both the text and its protagonist express themselves, in particular with respect to so-called scientific language. Instead of simply labeling Borg's use of diction and that of the text respectively, the following analysis focuses on the relation between science and language, especially gendered language. It is impossible to decide whether the reader is thrown back onto a primarily poetic language scattered with scientific vocabulary or instead onto a scientific discourse transmogrifying into poetic language. Still, the

I8. Here I use Londa Schiebinger's terminology. She argues that Linnaeus's "scientization' of botany coincided with an ardent 'sexualization' of plants" (I2, italics added). 
question itself is misleading; therefore, I would rather speak of hybridity, and more precisely of a bybrid language, formed and transformed out of elements belonging to different discourses that are balancing on the fine line between science and poetry, male and female.

I. Repeatedly, Axel Borg's obsessive will to order and to classify becomes obvious when he talks about language and appropriate language use. His rigorous requirements with regard to the order of things accompanied by his obsession with taxonomies apply just as well to his notion of language in general. Language, according to Borg, has to be clear, unambiguous, and precise. Again, the Swedish father of modern taxonomy serves as a reference point: Axel Borg, as I argue, is depicted as a Faustian ${ }^{19}$ scientist who slips into the role of one of his intellectual forefathers, Carl Linnaeus. ${ }^{20}$ The latter too was obsessed with the fundamental order of knowledge and with the development of a radically new language for botany. In the different editions of Systema naturae, Linnaeus invents a precise and convenient system of botanical and zoological nomenclature. Behind this preoccupation with order, both in Linnaeus and Strindberg, lurks the belief that all of nature can be tabulated and classified in a system. Thus a placid confidence in taxonomy is also a major characteristic of Borg's world view and language:

För att komma människodjurets organisation närmare på spåren anlade han särskilda studier över alla de lägre djurens själsförmögenheter och sökte sig därigenom fram till människan... Det var ett otroligt stort arbetsmaterial, och när han rett ut virrvarret såg han att mänskorna kunde indelas såsom djuren och växterna $i$ stora klasser, ordningar och familjer alltefter som indelningsgrunden bestämdes. (49-50)

In order to study more closely the way in which man the animal is organised, he devised individual studies on the mental ability of all the lower animals, and found his way through these up to man.... The material he amassed was enormous, and when he had reduced muddle to order, he realised that human beings could be classified like animals and plants in large classes, types and families, according to the method of classification used. (46)

19. Like Goethe's Faust, who, in the second part of the tragedy, transforms the coastline into an idyllic Garden of Eden, Borg attempts to remodel one of the skerries into an Italian landscape; he also tries to fabricate a homunculus reminiscent of the experiments of Faust's famulus, Wagner.

20. For an illuminating discussion on Linnaeus and style, see Christopher Oscarson's article on the "Re-invention of Carl Linnaeus as Ecological Subject." 
Borg takes it for granted that the perfect order of things will enable the skillful scientist to solve Ernst Haeckel's "Welträtsel" (The Riddle of the Universe), and self-confident and determined, he sets to work on ordering the realm of minerals: "[Borg] satte sig till att ordna.... [Han] insåg förberedande att det icke var stenarne som voro ordnade av naturen, utan att det var hjärnan som ordnade företeelserna. Och för övrigt, ordnas kunde allt, endast man skaffade sig en indelningsgrund" (47) [Borg "immediately set to work with a will, and began to put them (rocks and minerals) in order.... He realised for a start that it was not the stones which were by nature in an ordered state, but that it was the brain that arranged the facts. For that matter anything could be put in order if you only adopted a principle on which to base your classification" (43)]. Not surprisingly, the act of systematizing and giving names to things is, once more, a way of knowing them. Knowledge deals importantly with names and naming, but it is simultaneously an act of powerful appropriation. In particular scientific naming proves to be a matter of domination and domestication of, among other things, natural forces: "The desire to name scientifically is tantamount to an attempt to objectify and master a natural force from a distinctive perspective" (Stern 228). Again, this recalls the opening sequence of I havsbandet; nature and natural powers are broken down, and man pits himself against the elemental forces of the sea. Yet, there is one main difference: the sea voyage in the novel is part of the text's histoire, whereas the matter of scientific naming is closely enmeshed with the discursive level of the text. Borg's trip serves as a narrative prelude to what is also taking place on the level of discourse: the domestication through language and naming.

Once again, it is Linnaeus who brings into play the issue of classification and language but also of classification and names. Inventing an absolutely precise and convenient binomial nomenclature, ${ }^{21}$ he developed a radically new and ground-breaking language for botany. His ideas of a correlation between taxonomy and language are indeed promising for the analysis of I havsbandet, and Strindberg himself repeatedly establishes a close connection between Linnaeus's works and his own writing. In his poetic botanical sketch "Blomstrens Hemligheter"

\footnotetext{
2I. Programmatically, the Oxford Dictionary of English defines the term "nomenclature" as "the devising or choosing of names for things, especially in a science or other discipline," among other sources referring to the Linnaean system of zoological nomenclature.
} 
(The Secret of the Flowers), Strindberg gives an intriguing description of none other than Carl Linnaeus:

På I700-talet föddes en stor poet som ägnade sig åt naturvetenskaperna. Med poet menar jag en herre som har fantasi, det är formaiga att kombinera företeelser, se sammanhang, ordna, och gallra... Linné kunde under sina tjugofyra klasser inordna alla världens växter, och han kunde sitta hemma $i$ Uppsala och spära på att varbelst en ny växt påfunnes, skulle den vara nödsakad krypa in $i$ naggon av hans klasser.

Det var storartat och hur han bar sig àt att dikta dessa klasser, det veta vi inte och kanske inte han visste det heller, lika litet som naturmatematikern vet hur hans huvud löser problem som fordra andra gradens ekvationer.

Linnés system var emellertid inte vackert och inte korrekt. (215)

(In the eighteenth century, a great poet was born, who dedicated his life to the natural sciences. By poet, I mean a gentleman with imagination, which is the ability to combine phenomena, see connections, order, and weed out.... Linné could arrange all the world's plants into his twentyfour classes, and from his home in Uppsala, he would swear that all newly discovered plant would be forced to creep into one of his classes.

It was grand, how he set to work on composing these classes, but how this was done is something we cannot know and perhaps he did not know either, just as the mathematician does not know how his head solves problems requiring second order equations.

Linné's system was, however, neither beautiful nor correct.)

This portrait of Linnaeus is striking. As if it were the most natural thing to say about the Swedish nestor of taxonomy, Strindberg calls him a poet, even a great poet who also occupied himself with natural science. This depiction, as I would argue, can be read as an instruction manual for the literary figure Axel Borg though in an inverted mirror. In opposition to Linnaeus, Borg acts as a natural scientist who also occupies himself with questions of language and poetry. Linnaeus, as Strindberg portrays him in "Blomstrens Hemligheter," and Axel Borg have one main thing in common: they balance between two fields of study, between two disciplines, between science and poetry.

In Les mots et les choses (The Order of Things), Michel Foucault discusses Linnaeus's lifelong pursuit of order: "la connaissance des individus empiriques ne peut être acquise que sur le tableau continu, ordonné et universel de toutes les différences possibles" (I57) [“a knowledge of empirical individuals can be acquired only from the continuous, ordered, and universal tabulation of all possible differences" (I44)]. Knowledge and taxonomy are closely intertwined in Linnaeus's effort to establish 
a seamless and universal scientific language, particularly suitable for the categorization of both animate and inanimate nature. Moreover, Linnaeus calls for a purification of scientific language since "uti denna wettenskapen måste man ändteligen förskaffa sig rena principier" ("Fundamenta Botanica" 55) [within this science one eventually has to establish pure principles]. This echoes Axel Borg's answer to Maria's straightforward question: "Vad är det för språk[?] ... - Rent språk!" (89) [“"What kind of language is that?' ... 'Plain language"” (88)] (here I would add that rent can mean "pure"). Both Linnaeus and Borg try to establish a concept of purified language suitable for scientific purpose. Language has to be freed from all traces of simplification and everyday speech. In his endeavor to purify the things' names, Linnaeus states that "[namn] bör vara säkra och väl grundade, ej vaga, otydliga och med osäker tillämpning" ("Naturens alfabet" 428) [names have to be reliable and well-founded, not vague, unclear, and with uncertain usage]. It is striking that both Linnaeus and Strindberg strive for such a purification of language's ambiguity by invoking the proper names of the things. Axel Borg too condemns common speech for its inadequacy, but since language has to use everyday words, the focus shifts to the selection of words and phrases. In I havsbandet, this creates the texture of a precisealmost over-precise-diction: "Den ljusa, eleganta euriten, där svagt rosenröd fältspat lagrat sig med lätt blågrön kvarts, och glimmern endast gav sig tilkänna genom ett skimmer som av mikroskopisk rimfrost, gav hela det lilla landskapet en glad ton, och klyftad i oändlighet, erbjöd den soffor och verkliga länstolar vid varje steg" (62) ["The elegant, lightcoloured eurite, in which strata of faintly pink feldspar alternating with light blue-green quartz and mica only made their presence known by a shimmer like that of microscopic hoar-frost, gave all this little bit of landscape a happy aspect, while the endless crevices provided sofas and real armchairs at every step" (59)]. The substitution of everyday words for complex and ornate expressions characterizes the numerous nature and landscape descriptions in I havsbandet, in particular when it comes to nuances and shades of colors the choice of words becomes rich and variable: "Vilken skala av de finaste färger från svedlavens tuschsvarta, genom stenlavens askgrå, sköldlavens läderbruna, ringlavens Scheelesgröna och lunglavens fläckiga koppargröna, vägglavens äggula” (94) ["What a scale of the most delicate colours, from the Indian-ink black of the ramaline lichen through the ash-grey of the crottle, the leatherbrown of the ground liverwort, the Scheele's green of the parmelia 
lichen, the spotted copper-green of the lungwort, to the egg-yellow of the wall-moss" (93)].

But how are we to comprehend this elaborate and florid transformation of the visible into language? The description seems to be given by an analytical and rationally minded natural scientist who uses, among other discourses, the highly specialized language of petrology, the science of rocks. On closer inspection, however, the use of technical terminology is not enough to conclude that Axel Borg actually uses a scientific rhetoric. Scientific language, in Strindberg's text, is transfigured by poetic language and creates the texture of still another type of language - a "third language," much closer to poetry than to the dry language of classification. Obviously, the description of the eurite as "elegant" does not fit with a strictly scientific nomenclature. Here, Foucault provides us with a term that might help to shed light on the distinction between scientific and poetic.

In investigating Linnaeus's systematic and highly complex language, the French philosopher writes the following: "Si bien qu'au-dessus des mots de tous les jours (et à travers eux puisqu'on doit bien les utiliser pour les descriptions premières) se bâtit l'édifice d'une langue au second degré où règnent enfin les Noms exacts des choses" (Foucault, Les mots 172) ["So that above the ordinary, everyday words (and by means of them, since it is of course necessary to use them for the initial descriptions) there is raised the edifice of a language in the second degree in which the exact Names of things finally rule" (I59)]. Foucault's concept of a "language in the second degree" is quite challenging and can be used to take a closer look at the similarities and differences of the concepts of scientific and poetic language in $I$ havsbandet. To describe this language in even more detail, Foucault uses the term "bien faite" (I72) ["well-constructed" (I59)], which aims at descriptive exactitude and a clear articulation of the place each being occupies in the general arrangement of the whole. Accordingly, a term is introduced that can be used to label both Borg's and the text's language: their language is well-constructed. Both the ironic tone and the very complex syntax, as can be seen in the above-cited passages, decompose the language of everyday life - just in order to recompose it. Both Linnaeus's and Strindberg's texts "défait celui [le langage] de tous les jours, mais pour le refaire et découvrir ce qui l'a rendu possible à travers les ressemblances aveugles de l'imagination" (Foucault, Les mots 174) [“(decompose) the language of everyday life, 
but in order to recompose it and discover what has made it possible through the blind resemblances of imagination" (I6I)]. Language and speech are thus not so much about establishing practical systems, but rather about establishing an unique and radical order of speaking and knowing.

Keeping in mind that Foucault's concept of a language in the second degree explicitly refers to Linnaeus and his highly metaphorical language of botany, the question is how this should be compared to the language of Strindberg's novel and its protagonist's. Taking a closer look at an exemplary passage from Linnaeus's "Præludia Sponsaliorum Plantarum" (Prelude to the Betrothal of Plants), some striking similarities can be observed:

Siälfwa bladen i Blomman (:petala :) contribuera till generationen ingen ting, utan allenast giöra tiänst af Brudesängar, som den store Skaparen så bärligen inrättat, med sä ädla Sparlakan ubtstofferat, och med så mainga liufwa luchter parfumerat, på dett Brudgumen med sin brud där uti må fira sina Nuptias med så mycket större solennitet. Når sängen nu så blifwit tillagat, är tijd att Brudgumen omfamnar sin kära Brud, och henne sina håfivor upoffrar; jog menar, dà ser man huru testiculi öpna sig och effundera pulverem genitalem, som faller på tubam och foecunderar ovarium. (I4)

(The petals (: petala :) themselves make no contribution to the reproduction, and serve only as a bridal bed, marvelously fashioned by the Creator, with noble bed sheets, fragranced with delightful scents, for the groom and his bride to celebrate their Nuptias with greater solemnity. When so the bed is ready it is time for the groom to embrace his bride and offer his gifts; it appears to me that here we can witness how the testiculi opens and drops the pulverem genitalem, which falls on the tubam and fertilizes the ovarium.)

Both Linnaeus and Strindberg use a very complex and remarkably rich language that catches the reader's attention. They both use domainspecific terminology, for example, from the fields of petrology or botany. Linnaeus uses even loanwords and Latinisms, the famous "liberal sprinklings of Latin words and phrases" (Oscarson 408) that appear frequently when alluding to explicit sexual imagery (Nuptias, testiculi, pulverem genitalem, tubam, foecundera, ovarium). Particularly inspiring is the "parallel action" concerning the nature/culture difference: while Linnaeus translates a natural phenomenon, the fertilization of plants, into a cultural primal scene-the wedding night-something similar can be found in Strindberg as well. In I havsbandet natural scenes are 
culturally reshaped by describing geological formations in the archipelago as, for example, sofas and armchairs, ${ }^{22}$ i.e. as cultural objects. Nevertheless, there is one main difference: only Linnaeus gives an explanation for his use of metaphorical language by adding "jag menar, då ser man" ("Præludia Sponsaliorum Plantarum" I4) [it appears to me that here one sees] thus destroying the illusion of the self-contained aestheticized image of the wedding night. Linnaeus seeks to explain his metaphors and imagery and in this manner seeks to produce knowledge. His metaphorical language, as I would argue, is first and foremost aimed at the transmission and expansion of the knowledge of nature. Interestingly, Georges-Louis Leclerc, comte de Buffon, the French naturalist known for his "cold, exact rationality" (Oscarson 423), describes Linnaeus's system of nomenclature as "merely a language, easy to learn and recite but contributing nothing to the knowledge of nature" (quoted in Schiebinger 28). I do not agree with Buffon and would rather argue that Linnaeus's "language of exact names" is primarily designed to contribute to the knowledge of nature; Linnaeus wants to know, and he wants his readers to know, to acquire knowledge. Once more, the insight that naming and knowledge are intimately connected turns out to be true: "Om vi inte känner tingens namn, är kunskapen om dem förlorad" (quoted in Nynäs Io) [If we do not know the names of things, we lose the knowledge of them].

Strindberg's text, on the other hand, is not at all interested in the production of knowledge. It is, in contrast, interested in the aesthetic and ironic presentation of knowledge, especially contemporary scientific knowledge as has been sufficiently documented by Strindberg scholarship. Consequently, scientific language not only appears as a manifestation of cultural mastery, but also as the indomitable will to subordinate language by means of language. This suggests one more aspect that, by far, exceeds the scientific fabric of the narration, namely the interplay of language and gender. Text and language in $I$ bavsbandet are to such an extent well-constructed that they run perfectly well not only along spatial borders (archipelago) or language borders (science, poetry), but also along gender borders and gendered borders. This contravenes the scholarly tradition of labeling Borg's language as scientific and, more importantly, shows that those readings fail to do

22. See Strindberg, I havsbandet 80. 
justice to the radical nature of the poetization of scientific language, strikingly inspired by Carl Linnaeus.

II. Borg is a technocrat who, through science and scientific naming, seeks to establish a new language - a primarily male language. This male language is first of all characterized by its precision; it has to be clear, unambiguous, and concise and is thus congruent with the concept of a language in the second degree as delineated above.

Yet, at the other end of the language scale, we find the language of the others, the language of the insulars and women, in particular Maria's language, which turns out to be an essentially female language: "Ordrepertoaren var icke stor, det var de vanligaste talesätten av bildat umgängesspråk, utan alla konkreta, färgrika uttryck och där det fanns något bestämt angivet var det inkorrekt. Den talade om trädens grönska utan att ange namnen på träden, kallade trutarne måsar, bofinken en fågel, gnejsen granit, säven vass” (64) [“The vocabulary was not large, the speech was that of the most ordinary cultured conversation. It was completely lacking in concrete, colourful expressions, and whenever any definite information was given it was incorrect. The voice mentioned the foliage of the trees, but failed to name the species, it called blackbacks gulls, the chaffinch a bird, gneiss granite, rushes reeds" (6I)]. Consequently, the other's language is an unsophisticated and erroneous way of speaking lacking the concrete and colorful expressions, which characterize Borg's own language. As shown in the quotation above, he constantly points to the discrepancies between the perceived and the expressed (lacking, incorrect, failed), and it becomes obvious how closely language and perception are intertwined. The simplicity of everyday language corresponds to the plainness and simplicity in the other's way of speaking and thinking, and Borg mocks the unhappy many who are not able to make use of their understanding and language without direction from another. They cannot verbalize what they see, and they do not see what they actually say. Their perception and language is "allt så naivt som ett barns förenklade uppfattning av den rika naturens oändliga mångfald av former och färger, vilka endast det högt utbildade ögat kan se” (68) ["as naive as a child's simple conception of rich nature's infinite variety of form and colour, which only a highly trained eye can discern" (65)]. The "highly trained eye" is, of course, the scientist's eye, i.e. the man's eye. And from this it follows that the highly trained language is a strictly male language. Furthermore, their language does not differentiate; it is not able to differentiate, and it is not differentiated. Female speech, 
according to Borg, is undifferentiated speech while his own language is "[det] manliga, betydelseskiljande språk[et]" (Fahlgren I35) [the male language differentiating between meanings].

Just as there is male and female language, there is, according to Borg, even male and female poetry: "Intendenten hade först hört på, men slutligen dragit sig tillbaka med förklaringen att den svenska poesien vore skriven för konfirmander och damer, och att han väntade tills det komme en skald som skrev för män. Han hade då vid gemensam omröstning förklarats opoetisk" (I45) ["The inspector had listened at first, but had later withdrawn, explaining that Swedish poetry was written for confirmation candidates and ladies, and that he would wait until there was a poet who wrote for men. By a unanimous vote he was declared "unpoetical"' (I46)]. Borg goes to such lengths as to declare that only men can use differentiated language and that the only serious poetry is poetry for men - written in male language, exclusively by men. Again, this suggests not only two different orders of language and two different orders of poetry, but also two different orders of knowledge: a male and a female one.

In chapter seven, Borg illustrates the difference between poetic (i.e. female) and scientific (i.e. male) language, using as example the description of the sound of the sea:

Hör nu på vågornas brus, såsom poeterna summariskt kalla denna symfoni av ljud. Blunda ett ögonblick, så hör ni bättre, medan jag analyserar denna harmoni i enkla toner. Ni hör forst ett brus som liknar det man förnimmer $i$ ett maskinrum eller i en stor stad. Det är vattenmassornas slammer mot sig själva; därpå hör ni ett fräsande; det är de lättare mindre vattenpartierna som sönderpiskas till skum; och nu: ett skrapande som knivens mot slipstenen; det är vågens rivande mot sanden; och nu: ett rassel som när man tömmer en gruskärra; det är sjöns uppvräkande av smaistenarna; och sedan ett dunsande, dovt som när man slär den kupiga banden mot örat; det är vågen som pressar luften framfor sig $i$ en bålighet; och sist detta mullrande som av en avlägsen àska: det är de stora stenblocken som rullas på stenbotten. (94-5)

Listen now to the "roaring" of the waves, as the poets summarily call this symphony of sound. Shut your eyes for a moment and you will hear better while I analyse this harmony in single notes. You will first hear a roar, such as one hears in an engine-room or a big city. That is the great masses of water beating on themselves. Next you hear a hissing sound and that is the lighter, lesser units of water being whipped to scum. After that comes a scraping, like that of a knife against a grindstone. That is the wave grating against the sand, and 
then a rattling like someone emptying a cartload of gravel, and that is the waves tearing up the small stones. This is followed by a dull thud such as you hear when you hit your ear with a cupped hand. That is the wave pressing the air ahead of it into a cavity. Finally comes a rumbling as of distant thunder, and that is the great blocks of rock being rolled about on the stony bottom. (94)

First of all, a distinction is made between the poet's conventional and "summariskt" (94) [summary] language and the precise and analytical language Borg claims for himself. Poets, he argues, do not differentiate when it comes to the description of natural phenomena and are satisfied with calling the highly differentiated symphony of sound simply "vagornas brus" (94) [the roaring of the waves]. He himself, on the other hand, pretends to make an in-depth analysis of the sound of the sea: what follows, however, is not a harmonic analysis of nature's "water music," but rather a highly poetic description of the sound of the waves, littered with evocative images and metaphors. It is by no means accidental that the images, for the most part, are taken from the urban culture and, explicitly, from the engine room. Once more the boundaries between different spaces and domains are transgressed, and the protagonist uses the imagery of urban civilization (city, knife, grindstone, pushcart) in order to describe the natural space of the roaring sea. Thus, (the language of) civilization and technology overrides (the language of) nature, as we have already seen in Carl Linnaeus's description of the fertilization of the plants as a wedding night.

Of vital importance in this context is the fact that Linnaeus's scientization of natural phenomena is at the same time a sexualization. As is generally known, his botanical taxonomies are based on sexual differences, and the sexuality of the plants is the master key to the Linnaean classification system. Gender attributions are used to structure biological taxonomies, and the fertilization of the plants is described with elaborate human sexual metaphors. Particularly the imagery of the wedding night has proved to be distinctive: "Ja kärleken angriper siälfwa örterna, då ibland dem både mares och foemninæ, ja siälfwa Hermaphroditerna hålla sina nuptias, hwilket är dett jag nu sat mig före omatala, och wisa af siälfwa örternas genitalia, hwilka äro Mares, wilka Foemninæ och hwilka Hermaphroditer" (Linnaeus, "Præludia Sponsaliorum Plantarum" 8) [And love attacks even the plants, and among them both mares and foemninx, even the hermaphrodites celebrate their nuptias, which is what I will talk about, and show which of the plant's 
genitals are Mares, which are Foemninæ and which Hermaphrodites]. This revolutionary and radical language for botany is a "flowery" and sexualized language, establishing an elaborate system of classes in which all plants can be tabulated and adequately named. The very first and main criterion is always the sexual organ(s); flowering plants are classified into twenty-four classes of phanerogams according to the number of stamen and pistils. ${ }^{23}$ Unsurprisingly, it is always the male reproductive organ that supplants the female organ and Linnaeus's Systema sexuale is strictly hierarchical when it comes to the order of the sexes. ${ }^{24}$ Axel Borg too builds his classification systems along gender borders, i.e. gendered borders. According to Borg, solely the male scientist is able to "decipher laws from the great encrypted book of nature" (Schiebinger 8 ); only he is able to speak, to see, to conquer. Science, the methodical study of animate and inanimate nature in order to organize knowledge, becomes the ultimate epitome of manliness.

This is the last piece of the puzzle in the attempt to establish a pure, scientific, and male language: deprived of the right to know, deprived of her language, and exposed as an "ornamental plant" merely defined through her sexual organ, the woman has to be excluded from the communion of the knowing.

At this point, it is illuminating to close the argumentative circle by drawing a parallel between Borg's ostentatious seizure of power in the opening scene and his language use. Language is implicitly and explicitly used to exercise power and to justify and perpetuate the male boundary violations. The technocrat's highly precise language of power, even if ironically fractured, is saturated with metaphors of knowledge transfer and scientific superiority. At the same time, the variety of descriptive imagery that pervades the so-called scientific language is striking in suggesting that there actually does exist a close correspondence between male language and poetic language. The right to both poetry and knowledge

23. For a detailed discussion of the analogy between animal and plant sexuality see Schiebinger. She elaborates: "in the male, the filaments of the stamens are the vas deferens, the anthers are the testes, the pollen that falls from them when they are ripe is the seminal fluid; in the female, the stigma is the vulva, the style becomes the vagina, the tube running the length of the pistil is the Fallopian tube, the pericarp is the impregnated ovary, and the seeds are the egg" (2I).

24. The best known literary adaption of the Linnaean sexual system of the plants is certainly Erasmus Darwin's poem The Love of the Plants from 1789. Darwin uses the form of the didactic poem to promote Linnaeus's nomenclature and taxonomic system with the clear intention to provide knowledge by means of poetry. 
in Strindberg's text seems to rest with men, which further confirms the observation that there are two different orders of verbalizing and thinking: the superior male and the inferior female. Hence, the unreasonable others with their simple minds and plain language are placed outside the circuit of the speaking, the writing and the knowing. Accordingly, in I havsbandet, knowing, speaking and writing (poetry) are questions of gender and, in the end, a question of knowledge. By focusing on the problem of scientific male self-empowerment as a matter of radicalization of textual space and language, the article depicts both notions of hybridity foreshadowing seminal mid-twentieth-century theories of boundary-crossing and the precarious tightrope walk between different spatial, scientific, and gendered orders of things.

\section{Works Cited}

Barck, Karlheinz. "Avantgarde.” Ästhetische Grundbegriffe: Historisches Wörterbuch in sieben Bänden. Ed. Karlheinz Barck. Vol. I. Stuttgart: Metzler, 2000.

Beer, Gillian. "Writing Darwin's Islands: England and the Insular Condition." Inscribing Science: Scientific Texts and the Materiality of Communication. Ed. Timothy Lenoir. Stanford: UP Stanford, 1998. II9-39.

Berendsohn, Walter A. August Strindbergs skärgårds- och Stockholmsskildringar: Strukturoch stilstudier. Stockholm: Rabén \& Sjögren, 1962.

Blumenberg, Hans. Schiffbruch mit Zuschauer: Paradigma einer Daseinsmetapher. Frankfurt: Suhrkamp, I997.

. Shipwrecks with Spectator: Paradigm of a Metaphor for Existence. Trans. Steven Rendall. Cambridge: MIT P, I997.

Darwin, Charles. On the Origin of Species. Ed. Gillian Beer. Oxford: up Oxford, 2008.

Fahlgren, Margaretha. Kvinnans ekvation: Kön, makt och rationalitet $i$ Strindbergs författarskap. Stockholm: Carlsson, 1994.

Foucault, Michel. "Des espaces autres." Dits et écrits 1954-1988. Vol. 4. Eds. Daniel Defert and François Ewald. Paris: Gallimard, 1994. 752-62.

. "Different Spaces." Trans. Robert Hurley. Aesthetics, Method, and Epistemology: Essential Works of Foucault 1954-1984. Ed. James D. Faubion. New York: New, 1998. 175-85. . Les mots et les choses: Une archéologie des sciences humaines. Paris: Gallimard, 1966. . The Order of Things: An Archeology of the Human Sciences. New York: Vintage, 1994.

Frängsmyr, Tore. Geologi och skapelsestro: Föreställningar om jordens historia från Hiärne til Bergman. Uppsala: Almqvist \& Wiksell, I969.

"island" Oxford Dictionary of English. Eds. Catherine Soanes and Angus Stevenson. Oxford: Oxford UP, 2003.

Linnaeus, Carl (Linné, Carl von). "Præludia sponsaliorum plantarum.” Ed. Theodor Magnus Fries. Vol. 4. Skrifter. Uppsala: Almqvist \& Wiksell, 1908. I-26.

. "Fundamenta Botanica." Carl von Linné: Om botanikens grunder. Föreläsningsanteckningar, Höstterminen 1748. Ed. Carina Nynäs. Trans. Lars Berquist. Stockholm: Atlantis, 2007. 5I-426. 
"Linné om Naturens alfabet, stavelser och glosor." Carl von Linné: Om botanikens grunder. Föreläsningsanteckningar, Höstterminen 1748. Ed. Carina Nynäs. Trans. Lars Berquist. Stockholm: Atlantis, 2007. 427-40.

Makropoulos, Michael. "Modernität als Kontingenzkultur. Konturen eines Konzepts." Kontingenz. Eds. Gerhart v. Graevenitz and Odo Marquard. München: Wilhelm Fink, 1998. 55-79.

. "Meer." Wörterbuch der philosophischen Metaphern. Ed. Ralf Konersmann. Darmstadt: Wissenschaftliche Buchgesellschaft, 2007. 236-48.

"nomenclature." Oxford Dictionary of English. Eds. Catherine Soanes and Angus Stevenson. Oxford: Oxford UP, 2003.

Oscarson, Christopher. "Linnaeus 1907: Oscar Levertin and the Re-invention of Carl Linnaeus as Ecological Subject." Scandinavian Studies 79.4 (2007): 405-26.

Schiebinger, Londa. Nature's Body: Gender in the Making of Modern Science. Boston: Beacon, 1993.

Stenport, Anna Westerståhl. Locating August Strindberg's Prose: Modernism, Transnationalism, and Setting. Toronto: UP Toronto, 2010.

Storå, Nils. "Landscape Territory, Autonomy, and Regional Identity: The Åland Islands in a Cultural Perspective." Nordic Landscapes: Region and Belonging on the Northern Edge of Europe. Eds. Michael Jones and Kenneth R. Olwig. Minneapolis: U Minnesota P, 2008. 440-57.

Stockenström, Göran. "The World that Strindberg Found: Deciphering the Palimpsest of Nature." August Strindberg and the Other: New Critical Approaches. Eds. Poul Houe, Sven Hakon Rossel, and Göran Stockenström. Amsterdam: Rodopi, 2002. I5-42.

Strindberg, August. I havsbandet. Ed. Hans Lindström. August Strindbergs samlade verk. Vol. 3I. Uppsala: Almqvist \& Wiksell, 1982. By the Open Sea. Trans. Mary Sandbach. Athens: U Georgia P, 1984. . “Blomstrens Hemligheter.” Ed. Hans Lindström. August Strindbergs samlade verk. Vol. 29. Vivisektioner. Uppsala: Almqvist \& Wiksell, 1985. 206-I8. . “Skärkarlsliv. Berättelser.” Ed. Nils Åke Sjöstedt. August Strindbergs samlade verk. Vol. 26. Uppsala: Almqvist \& Wiksell, 1984. 